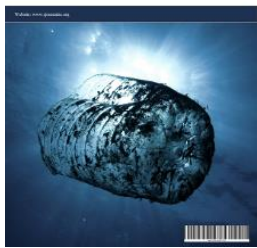

\title{
The Role of Viral Marketing in Social Media on Brand Recognition and Preference
}

\author{
Wilert Puriwat ${ }^{1}$, Suchart Tripopsakul ${ }^{2 *}$ \\ ${ }^{1}$ Chulalongkorn Business School, Chulalongkorn University, 254 Phayathai Rd, Wang Mai, Khet Pathum Wan, Krung Thep Maha \\ Nakhon 10330, Thailand \\ ${ }^{2}$ School of Entrepreneurship and Management, Bangkok University, 119 Rama 4 Road,Klong-Toei, Bangkok 10110, Thailand
}

\begin{abstract}
Viral marketing is one of the most effective and imperative marketing strategies. The prominence of digital technology and social media has elevated the importance of viral marketing campaigns by increasing their cost efficiency and enabling them to reach targeted audiences rapidly. This study aimed to examine the influence of viral marketing strategies on brand recognition and brand preference by developing a framework for the effectiveness of viral marketing (7I's) in socia media contexts and testing the associations among the 7I's, brand recognition and brand preference. A quantitative research method with a structured questionnaire as the research tool was employed to collect data from a total of 286 respondents in Thailand. Structural equation modelling (SEM) was utilized to test the proposed hypotheses. The results showed that effective viral marketing relates positively to brand recognition $(b=0.440)$ and preference $(b=0.298)$. The mediation analysis also revealed that brand recognition partially mediates the relationship between effective viral marketing and brand preference. In terms of the moderating effects, the results indicated a stronger influence for effective viral marketing on brand preference among younger respondents $(b=0.336)$ than among older respondents $(b=0.278)$. This research makes a significant contribution to the existing literature by validating a theory-driven framework based on the novel concept of the 7I's and its potential effect on customers' brand perceptions.
\end{abstract}

\section{Keywords:}

Viral Marketing;

Social Media;

Branding;

Thailand.

Article History:

Received: 13 July 2021

Revised: $\quad 08$ October 2021

Accepted: $\quad 03 \quad$ November 2021

Published: $01 \quad$ December 2021

\section{1- Introduction}

Like viruses, viral marketing facilitates the swift and transformative spread of information across millions of people [1]. Viral marketing is sometimes referred to as word-of-mouth communication. To this concept, Klopper (2002) added the notion of 'word of mouse', suggesting that in the rapidly expanding digital environment, word-of-mouth communication spreads because the message appeals to the first recipient, who, in turn, sends the message to others via technological communication channels, such as email, texting, instant messaging and personal digital assistants (PDAs) [2]. These channels have accelerated the dissemination of information and opinions over the past decade [3].

Although Generation $\mathrm{Y}$ is adept at social media usage, which is the most important channel to enhance viral marketing, Bolton et al. (2013) and Gao et al. (2020) observed that social media is no longer restricted to young generations $[4,5]$. Given the popularity of social media, older generations are now, surprisingly, more frequent social networkers. In fact, women aged 55 years and older represent one of the largest demographics of Facebook users. Noting its ability to extend interactions and interpersonal connections, Oraedu et al. (2020) added that word-of-mouth

\footnotetext{
${ }^{*}$ CONTACT: suchart.t@bu.ac.th
}

DOI: http://dx.doi.org/10.28991/esj-2021-01315

(C) 2021 by the authors. Licensee ESJ, Italy. This is an open access article under the terms and conditions of the Creative Commons Attribution (CC-BY) license (https://creativecommons.org/licenses/by/4.0/). 
communication can take place not only among acquaintances, such as family, friends and co-workers, but even among strangers [6]. Marketers see these interactions as significant opportunities. In 2020, word-of-mouth marketing drove $\$ 6$ trillion of annual consumer expenditures, accounting for almost 13\% of sales. Furthermore, because people are $90 \%$ more likely to trust and make purchases from brands recommended by friends, word-of-mouth marketing impressions account for five times the number of sales driven by paid media impressions [7].

Despite its significant growth and value, viral marketing can be a double-edged sword. Marketers face inherent risks when implementing viral marketing campaigns [8, 9]. Klopper (2002) stated that word-of-mouth marketing must not only reach recipients but also produce positive perceptions [2]. Studies show that negative comments or reviews from influencers can be far more damaging when shared online [10]. This aligns with Wang et al. (2013) finding that negative information carries more weight and incites consumers' emotional responses more intensely [11]. Unfavourable wordof-mouth communication and the resulting backlash can thus impair a brand's image and products/services, cause unfavourable associations between products/services and boycotts, conflict with hate sites, etc. [8]. In contrast, effective viral marketing campaigns efficiently connect with the largest number of people and improve consumers' perceptions of the brand via the delivered content. Despite the numerous successes of viral marketing, little is known about the motivations of customers who choose to share content or the process by which content becomes viral. Indeed, relatively little research has evaluated word-of-mouth communication as well as the triggers and conditions inciting it [12]. Unlike other online advertising formats, which are shared directly by advertisers, viral advertisements are shared between acquaintances who have been influenced by the content. Therefore, the message must be effective enough to trigger a positive consumer response [13].

Although some studies have attempted to provide empirical evidence for the effect of viral marketing on customers' perceptions, only a few have offered a conceptual framework and guidelines for marketers and practitioners implementing effective viral marketing campaigns. To address this research gap, the present study proposes and tests a new concept - the 7I's of effective viral marketing. The results of this study, which validate the 7I's concept, fill a crucial knowledge gap and thus equip viral marketing strategists, academics and practitioners to design more effective viral marketing strategies, campaigns and programmes that are relevant to consumers.

This paper proceeds as follows. Section 2 provides a review of the literature regarding the viral marketing concept and its implications. Section 3 explains the research framework and develops the hypotheses. Section 4 illustrates the research methodology utilised for data collection. Section 5 presents and discusses the data analysis results. Section 6 offers the conclusion, including the limitations of this study and prospects for future research.

\section{2- Literature Review}

Viral marketing is the electronic form of word-of-mouth marketing, which encompasses news, environment and information [14]. While Grewal and Chahar (2013) demonstrated that word-of-mouth communication is generally performed offline, viral marketing combines internet technology and word-of-mouth tactics [15]. The characteristics of viral marketing are typically associated with the use of social media applications. However, Sohnet et al. (2013) suggested that viral marketing is not limited to a single medium of transmission [16]. Customer-to-customer exchangewhether societal or informational-is the result of the proliferation of broadband access, social media platforms, customer communities, status update services, wikis, blogs and video-sharing sites; thus, viral marketing now spreads at the speed of thought $[17,18]$. This facilitates social interaction opportunities, enabling communication among multiple people.

Previous studies have demonstrated that viral marketing greatly affects consumer decisions. Stonedahl et al. (2010) opined that viral marketing is more powerful than traditional marketing because consumers now rely heavily on word of mouth and discussions about a product to inform their purchase decisions [19]. According to Kaplan and Haenlein (2011), companies are increasingly aware of the growth in customer-to-customer interactions or viral marketing [20]. This growth can be attributed to the following factors. First, viral marketing allows companies to more efficiently promote their products or services and enhance brand awareness [21]. Viral marketing is less costly than other forms of marketing and advertising campaigns [8]. At the same time, however, it represents a significant investment in a company's strategy for building brand equity and thus enables a brand to distinguish itself from competing brands and products and creates a sustainable competitive advantage [22]. Second, viral marketing is considered more credible than marketer-initiated communications because viral messages are perceived as unbiased and 'coming from people like me' $[23,24]$. The concept of viral marketing, which, unlike paid testimonials and mass advertising campaigns, encourages the recipient to forward the message voluntarily, is consistent with this perception [21]. The information that consumers share usually stems from their personal experiences and thus impacts others' attitudes and resonates better than any particular information created by advertising companies and corporate marketing departments [25].

Numerous consumer decisions occur in a social environment. Bickart and Schindler (2001) and East et al. (2008) stated that personal interactions exert a greater influence over consumer choices than do personal selling, print advertisement or radio advertisement [26, 27]. Pescher et al. (2014) supported this idea by emphasising that the core difference between a viral advertisement and a television advertisement is that consumers seek out and enjoy viral 
advertisements and thus willingly sending them to others [28]. As early as 1979, Davis et al. (1979) offered an example of the service industry's dependence on word-of-mouth advertising [29, 30]. As they explained, intangibles, e.g. aftersale services, cannot be gauged before consumption. Hence, customers can only rely on word of mouth. Studies show that viral marketing is helpful for both new and existing brands. Viral marketing plays an important role in converting and retaining recipients as new users and enhancing brand penetration and loyalty [15]. The successful introduction of a new product is important for a firm's long-term performance [31]. Studies show that compared with traditional advertising, viral marketing can generate higher levels of consumer awareness and intentions of adopting a new product. Typically, the aim of viral marketing is to build the brand, which begins with the company composing electronic content, such as a mini-site or video [32]. López and Sicilia (2013) demonstrated that a firm should start new product communications with word-of-mouth marketing and then continue with traditional advertising [33]. Prins and Verhoef's (2007) study supported this assertion, finding that the higher the volume of word-of-mouth interactions, the faster consumers adapted to the new product [31].

Viral marketing has benefits for established products as well. Digital technology presents opportunities for building relationships - whether among peers or between marketers and customers [34, 35]. Blazevic et al. (2013) stated that customers influence not only each other's behaviours but also each other's attitudes by exchanging information about their experiences [36]. Thus, a company can improve its image based on consumers' positive perceptions of its message [37]. It is also important to note that positive word of mouth critically increases customers' purchasing intentions and reduces companies' promotional expenditures [38]. Indeed, marketers do not pay users of the Internet to propagate their information. Because users' decisions to forward information are entirely voluntary, however, it is essential for companies to understand the reasons behind these decisions [32]. Despite the rich literature on the effects and implementation of viral marketing strategies, no research has yet been conducted to investigate the characteristics of effective viral marketing [39, 38]. To manage viral marketing effectively, it is crucial both to explore consumers' motivations for posting online word-of-mouth messages and to measure the effectiveness of viral marketing campaigns $[11,40]$.

Based on a review of the literature, this paper identifies seven characteristics-the 7I's - of effective word-of-mouth marketing campaigns: Invisibility (IN), Identity (ID), Innovation (IO), Insight (IS), Instantaneity (IT), Integration (IE) and Interactivity (IR). Figure 1 outlines the proposed 7I's framework while the sections below detail the literature supporting each characteristic.

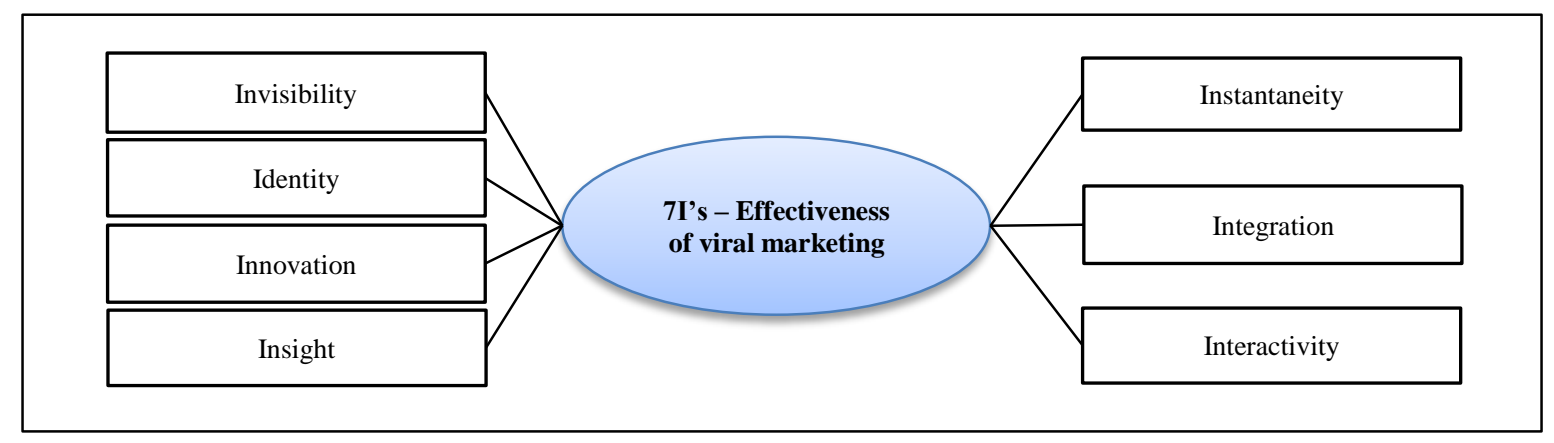

Figure 1. Proposed conceptual framework.

Invisibility: Grewal and Chahar (2013) suggested that consumers perceive content dominated by branding elements as too commercial, and therefore, they tend not to pass it on. Marketers can avoid these negative consumer perceptions and reactions by balancing the branding element with the quality of the content [15]. Consumers tend to favour messages in which the marketer's involvement is 'invisible' and the source is deemed credible. Accordingly, the study by Dobele et al. (2005) found that consumers tend not to share content directly from businesses [21]. Rather, for consumers, sharing information via social networks is about personal connections with friends and family. Furthermore, the results indicated that branding elements lower the credibility of the content in viral marketing messages and sometimes cause negative consumer perceptions to emerge. Previous research on social networking supports this result by showing that customers loathe to forward messages that violate social networking's innate qualities of trust and socialisation [41]. In this context, online influencers play an important role. Rather than appearing as the 'agents', marketers should be deemed as knowledgeable helpers in social networking [42]. Under such circumstances, the likelihood of consumers forwarding messages increases considerably. Therefore, they tend to obtain information from friends and other personal contacts [43]. This is because consumers are overwhelmed by the number of advertising messages they receive and thus actively avoid them [44].

Identity: In recent years, consumers have increasingly defined their personalities by sharing online content with their friends and family. Consumers engage with messages in viral marketing because they wish to align themselves with the content [38]. In other words, they might decide to share a message or even become a brand advocate because they anticipate that such actions will produce a positive impact on their own image or status. Jalilvand and Samiei (2012) reported that viral marketing considerably affects brand image and indirectly increases consumers' intentions to 
purchase a product or service [38]. To promote these positive effects, the study explained, marketers must know what consumers are saying about themselves when sharing messages. Whether they resonate with consumers' humour, fashion sense, tech-savviness or social contributions, effective messages must be clear and consistent with consumers' identities. Ho and Dempsey (2010) showed further those consumers are willing to stand out from others [32]. Consistent with this study, sharing viral content allows consumers to differentiate themselves and demonstrate their status among their friends. Grewal and Chahar (2013) supported this assertion by suggesting that viral content should integrate the brand with the story, whether directly or indirectly, and ensure that consumers are aware of the content-brand connection [15].

Innovation: After opening a message, individuals may simply move on or begin to engage with the content and process the information. Following the latter decision, they may decide to share the message. Exploratory research has demonstrated that consumers tend to prefer messages that utilise genuinely new and interesting forms of communication. As indicated by Southgate et al. (2010), the distinctiveness of an ad is an important factor in determining whether it will become a successful communication tool. Studying 102 video ads released in the United Kingdom, the authors suggested that a video advertising campaign's creative details correlate with the campaign's popularity [45]. Ibeh et al. (2005) refer to the distinctiveness that leads an audience to engage with viral marketing campaigns as unique messages, functionality and content [46]. The content of successful viral marketing campaigns might, for example, be exceptionally funny or outstanding enough in some other way to depart from the status quo and thus surprise consumers [15]. According to Dobele et al. (2005), successful viral marketing campaigns must disseminate an engaging, imaginative, entertaining and intriguing message [21].

Insight: The process of data analysis has identified many different types of viral marketing. Respondents stress that they share not just the content of viral marketing but also the feelings the content creates. They are, moreover, more willing to share an interesting story that is relevant to their lives rather than a list of product attributes. Marketers should thus consider whether the content matches an individual's insight—and if it matches, how it matches. In other words, the idea of the content should be relevant to the target audience. Accordingly, the respondents from the study of Grewal and Chahar (2013) were more willing to open and share viral marketing messages when they could relate to those messages in a positive way and the message exhibited great personal relevance [15]. Furthermore, Kotler and Keller (2018) recommended that viral marketing messages highlight some type of benefit or encouragement to engage with consumers [47]. They stated that both rational appeals and emotional appeals could comprise the message. While a rational appeal encourages purchase willingness by presenting product attributes, an emotional appeal can elicit consumers' positive emotions towards engagement. Indeed, Berger and Milkman (2012) suggested that people share useful content that is rich in information as well as positive content that elicits emotions. They also found that content that is funny, touching, surprising, interesting or even strange is more likely to be shared [48].

Instantaneity: Consumers are more likely to notice a viral marketing campaign if it reminds them of something that is currently popular. For example, Ferguson (2008) found that successful viral marketing campaigns capitalise on the human desire to appear trendy and in the know [17]. Consumers desire opportunities to tell their connections about novel products and thus garner attention, prestige and status through new product knowledge, experiences or ownership [14]. Celebrities may play an important role in spreading brands' messages as well. The respondents in the study of Southgate et al. (2010) demonstrated the importance of the presenter's credibility to the success of viral marketing campaigns [45]. $\mathrm{Wu}$ and Wang (2011) found that credible celebrities vouching for products incline consumer attitudes towards those products and thus render viral marketing campaigns - and, in turn, the brand - in a positive light. They further indicate that credibility increases when celebrities are considered more trustworthy and attractive. Trustworthiness refers to the professional knowledge the presenter has about the brand that makes the audience confident in the presenter. Attractiveness refers to the presenter's physical traits or status that could attract consumers to engage with viral marketing campaigns [49].

Integration: Viral marketing messages function as a gateway to connect brands with consumers through other channels. In fact, the most successful viral marketing campaigns impel audiences to do more than merely open and read the messages; in addition, the audiences of successful campaigns tend to engage subsequently with the brand via other channels. Hence, viral marketing campaigns achieve their full potential when synergised with other tools of marketing communication [14]. For instance, above-the-line work can be used to enhance the impact of viral marketing. As marketers construct their viral marketing campaigns, they must think about consumers holistically and consider their social interactions in the context of other consumer touch points with the brand. According to Baird and Parasnis (2011), if the customer is known in one channel, he or she must also be known in other channels. This means that viral marketing campaigns should not be used in isolation. Rather, they must be thoughtfully integrated with other channels [50].

Interactivity: Besides constructing the right message, viral marketers must also consider the level of interaction between the message and the targeted consumers. According to Fisher (2009), marketers can utilise the interaction rate as a metric when planning an effective campaign [51]. When the respondents featured in Fisher's research were asked how they interact with brands after being exposed to viral marketing messages, they listed 'Purchasing products and services' and 'Reading reviews and product rankings' as their top two activities [51]. This suggests that consumers require not just more interactions but more intimate interactions with a company. When consumers trust a brand and engage with it emotionally via viral marketing content, these interactions, in turn, facilitate the development of a holistic 
experience. The foremost step in the relationship chain leading to cross- and up-selling and enhanced customer lifetime value, customer identification is essential to promote the required high level of interaction [17]. Marketers already employ various methods to promote customer identification - for example, enlisting customers in opt-in plans, gathering e-mail addresses or tracking offer redemptions. Abrantes et al. (2013) found that consumers tend to share negative experiences with friends through social networks [52]. If marketers possess the ability to interact and communicate proactively with consumers, firms can capitalise upon those interactions to counter the effects of negative comments. Thus, a successful viral marketing campaign must be interactive. Several studies have recommended that marketers regard interactions with consumers as a vital opportunity to receive feedback by monitoring the information exchanged in social communities, e.g. Twitter, Facebook and LinkedIn. Marketers must, moreover, address this feedback proactively, especially when the feedback is negative $[52,53]$.

\section{3- Conceptual Framework and Hypotheses Development}

This research aims to investigate the impact of viral marketing strategies on customers' purchasing behaviours and intentions in social media contexts. To this end, the study proposes the 7I's framework for effective viral marketing. To test the moderation effects of generational differences on the links among the 7I's, brand recognition and brand preference, the proposed model also includes the respondents' ages. Figure 1 illustrates the proposed research framework.

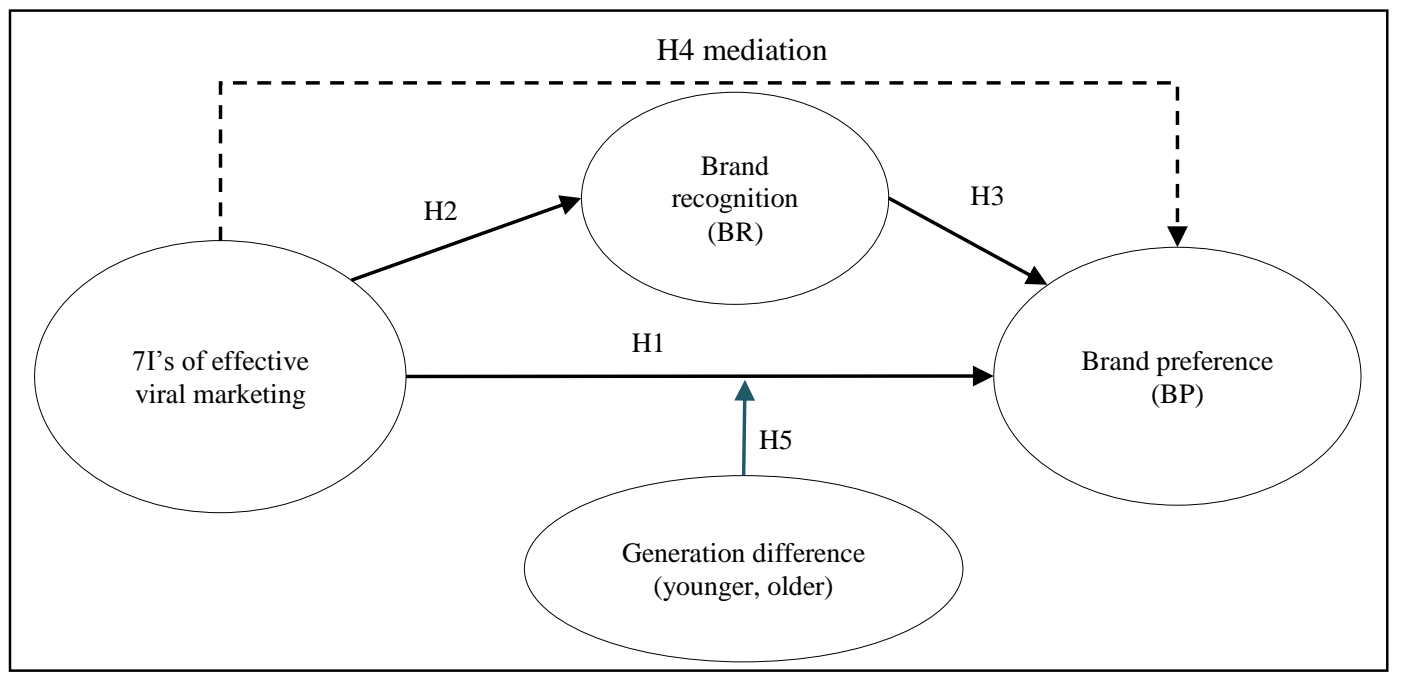

Figure 2. Conceptual framework of this study.

To examine the associations among the 7I's, brand recognition (BR) and brand preference (BP) with generational differences as a moderator, the study tests the following hypotheses:

Hypothesis 1: The 7I's of effective viral marketing have a positive, direct impact on brand preference.

Hypothesis 2: The 7I's of effective viral marketing have a positive, direct impact on brand recognition.

Hypothesis 3: Brand recognition has a positive, direct impact on brand preference.

Hypothesis 4: Brand recognition mediates the effect of the 7I's on brand preference.

Hypothesis 5: Generational differences among consumers (younger vs older) moderate the positive effect of the 7I's of effective viral marketing on brand preference such that the effect is stronger among younger respondents than among older respondents.

\section{4- Research Methodology}

\section{4-1- Research Design and Data Collection}

This study employed a quantitative method with an online survey questionnaire to examine the proposed research hypotheses and test the suggested model. The survey questions asked respondents to convey their perceptions of viral marketing strategies, campaigns or advertising they had recently experienced through social media. Structural equation modelling (SEM) via AMOS 22.0 was used to analyse the data, which were gathered via a purposive sampling technique. Anderson and Gerbing (1988) suggested at least 150 participants as an adequate sample size [54]; however, Bentler and Chou (1987) and Kline (2011) recommended that SEM analyses include at least 200 participants — or at least five cases per parameter for uncomplicated SEM models [55, 56]. Because this study contained 27 observables variables, the minimum sample size was $27 \times 5=135$. After gathering and filtering the data for analysis, 286 valid surveys were collected, exceeding the minimum sample size. Figure 3 presents the research methodology in a flowchart. 


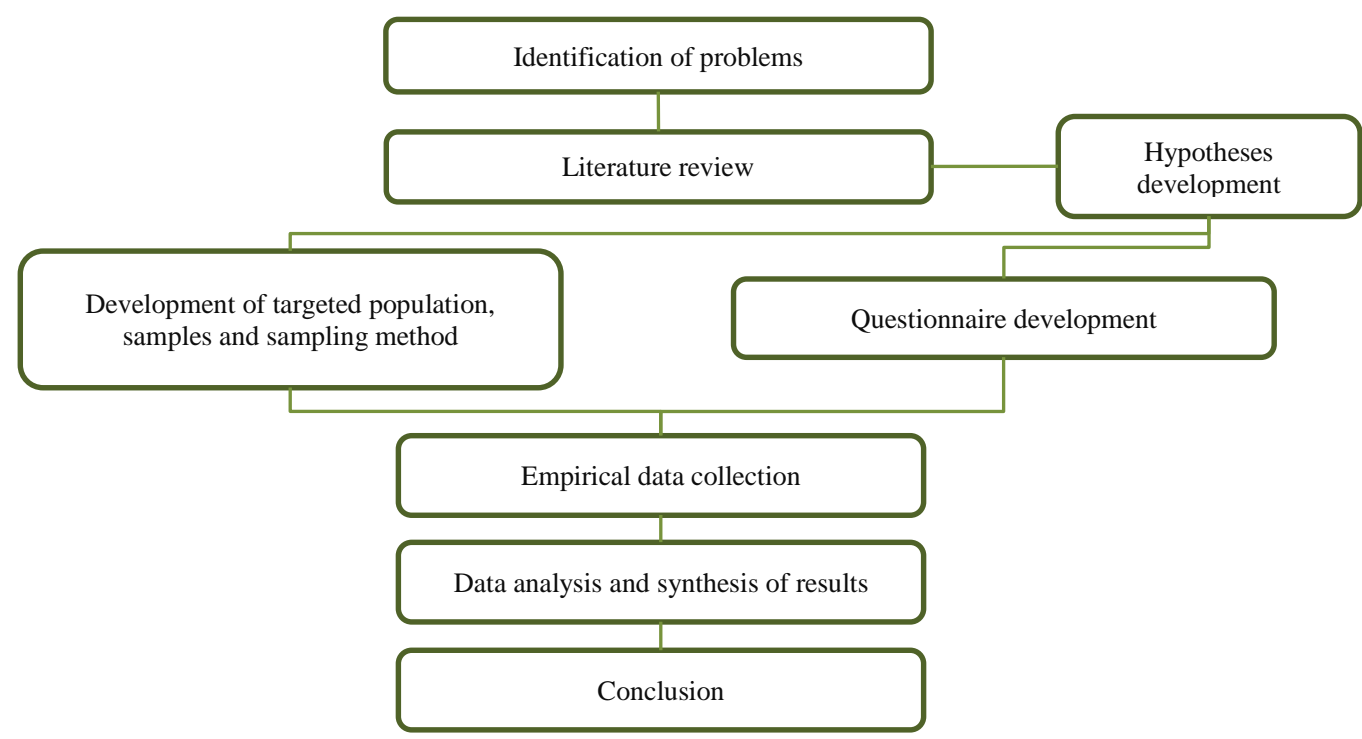

Figure 3. Flowchart of research methodology.

\section{4-2- Questionnaire Development}

The questionnaire comprised two sections: (1) basic information related to respondents' behavioural and demographic aspects and (2) the measurement items. A five-point Likert scale ranging from strongly agree (5) to strongly disagree (1) was used for the measurement items. In the suggested model, the independent variable- the 7I'sconsisted of seven sub-elements: Invisibility, Identity, Innovation, Insight, Instantaneity, Integration and Interactivity, which were calculated with 21 items. Brand recognition was calculated with three items adapted from Alhaddad (2015) [57]. Brand preference was assessed via three items adapted from Ebrahim et al. (2016) [58]. Table 1 illustrates the constructs and measurement scales.

Table 1. Questionnaire constructs and variables.

\begin{tabular}{|c|c|c|}
\hline Constructs & Items & Observed Variables \\
\hline \multirow{3}{*}{ Invisibility } & IN1 & Viral marketing messages from this brand are not too commercial. \\
\hline & IN2 & Viral marketing messages from this brand are unaware of the marketer's involvement. \\
\hline & IN3 & I do not feel overwhelmed by too many viral marketing messages from this brand. \\
\hline \multirow{3}{*}{ Identity } & ID1 & Viral marketing messages from this brand are clear. \\
\hline & ID2 & Viral marketing messages from this brand align with my identity. \\
\hline & ID3 & Viral marketing messages integrate this brand's identity into the content either directly or indirectly. \\
\hline \multirow{3}{*}{ Innovative } & IO1 & Viral marketing messages from this brand include genuinely new ways of communication. \\
\hline & $\mathrm{IO} 2$ & Viral marketing messages from this brand are interesting. \\
\hline & IO3 & Viral marketing messages from this brand contain unique messages, functionality and content. \\
\hline \multirow{3}{*}{ Insight } & IS1 & Viral marketing messages from this brand are related to me. \\
\hline & IS2 & Viral marketing messages from this brand match my personal insight. \\
\hline & IS3 & Viral marketing messages from this brand contain positive thoughts, and the message shows great personal relevance. \\
\hline \multirow{3}{*}{ Instantaneity } & IT1 & Viral marketing messages from this brand remind me of something that is currently the talk of the town. \\
\hline & IT2 & Viral marketing messages from this brand tap into my desire to appear trendy and in the know. \\
\hline & IT3 & The celebrity representing this brand's viral marketing messages possesses trustworthiness and attractiveness. \\
\hline \multirow{3}{*}{ Integration } & IE1 & Viral marketing messages from this brand synchronise with the brand in other channels afterward. \\
\hline & IE2 & Viral marketing campaigns from this brand thoughtfully integrate with other channels. \\
\hline & IE3 & I can easily link these viral marketing messages with the brand's other communication content and messages. \\
\hline \multirow{3}{*}{ Interactivity } & IR1 & Viral marketing messages from this brand allow me to read other audiences' reviews or comments. \\
\hline & IR2 & Viral marketing messages from this brand allow me to write any review or provide product rankings. \\
\hline & IR3 & Viral marketing messages from this brand allow me to purchase products or services after the exposure. \\
\hline \multirow{3}{*}{$\begin{array}{l}\text { Brand } \\
\text { recognition }\end{array}$} & BR1 & I am aware of the particular brand using effective viral marketing messages. \\
\hline & BR2 & I can distinguish this brand from other brands using viral marketing messages. \\
\hline & BR3 & I usually remember this brand name from among all of the circulating viral marketing messages. \\
\hline \multirow{3}{*}{$\begin{array}{c}\text { Brand } \\
\text { preference }\end{array}$} & BP1 & I like this brand better than others. \\
\hline & $\mathrm{BP} 2$ & This brand is my preferred brand over others. \\
\hline & BP3 & When it comes to making a purchase, this brand is my first preference. \\
\hline
\end{tabular}




\section{5- Results and Discussions}

\section{5-1- Sample Profile}

The data were acquired from an online questionnaire, which social media users in Thailand were invited to complete. After being asked to recall their most recent encounters with viral marketing messages via social media, respondents completed the questionnaire, which allowed them to express their views of those messages. Two hundred eighty-six valid questionnaires were submitted for analysis. Descriptive statistics in SPSS were employed to analyse the respondents' demographic characteristics. Table 2 reveals that $53.36 \%$ of the participants were female while $46.64 \%$ were male. Most respondents ranged in age from 18 to 25 years $(30.85 \%)$, and $52.52 \%$ were undergraduates who spent more than 4 hours $(48.5 \%)$ on social media daily.

Table 2. Descriptive statistics.

\begin{tabular}{cccc}
\hline Item & Description & Sample & $(\boldsymbol{\%})$ \\
\hline \multirow{2}{*}{ Gender } & Female & 153 & 53.36 \\
& Male & 133 & 46.64 \\
\hline \multirow{2}{*}{ Age } & $18-25$ & 88 & 30.85 \\
& $26-35$ & 79 & 27.56 \\
& $36-45$ & 76 & 26.52 \\
Education & $46-55$ & 32 & 11.23 \\
& More than 55 years & 11 & 3.84 \\
\hline \multirow{3}{*}{ Social media usage daily } & Below undergraduate & 4 & 1.56 \\
& Undergraduate & 150 & 52.52 \\
& Postgraduate & 131 & 45.92 \\
\hline & Less than 1 hour & 13 & 4.5 \\
& 1 hour-2 hours & 53 & 18.6 \\
& 3 hours-4 hours & 81 & 28.4 \\
& More than 4 hours & 139 & 48.5 \\
\hline
\end{tabular}

Note: $\mathrm{N}=286$; missing data are not shown in the table

\section{5-2- Measurement Model}

To assess the correlations between the constructs and their retained items, confirmatory factor analysis (CFA) was employed. The estimation included an overall goodness-of-fit test as well as separate tests for significance to assess the presumed relations among the variables. To assess the correlations between the constructs and their retained items, pooled confirmatory factor analysis (CFA) was employed. Following Awang's (2015) suggestion, the latent constructs of IN, ID, IO, IS, IT, IE and IR (second-order constructs of the 7I's) were pooled together with the BR and BP constructs [59]. Table 3 illustrates our measurement model's items and constructs.

Table 3. Measurement model's summary items and constructs.

\begin{tabular}{ccccccc}
\hline Constructs and items & Loading & t-value & SE & $\boldsymbol{\alpha}$ & CR & AVE \\
\hline II's & - & - & - & 0.897 & 0.917 & 0.612 \\
IN & 0.793 & - & - & - & - & - \\
ID & 0.798 & 14.586 & 0.107 & - & - & - \\
IO & 0.761 & 13.193 & 0.105 & - & - & - \\
IS & 0.782 & 13.536 & 0.181 & - & - & - \\
IT & 0.806 & 14.832 & 0.165 & - & - & - \\
IE & 0.748 & 12.893 & 0.086 & - & - & - \\
IR & 0.787 & 13.571 & 0.121 & - & - & - \\
Brand recognition & - & - & - & 0.913 & 0.875 & 0.702 \\
BR1 & 0.704 & - & - & - & - & - \\
BR2 & 0.881 & 15.975 & 0.075 & - & - & - \\
BR3 & 0.915 & 16.306 & 0.077 & - & - & - \\
Brand preference & - & - & - & 0.925 & 0.818 & 0.601 \\
BP1 & 0.741 & - & - & - & - & - \\
BP2 & 0.836 & 10.278 & 0.124 & - & - & - \\
BP3 & 0.744 & 9.825 & 0.127 & - & - \\
\hline
\end{tabular}

Notes: SE = standard error; only first-order constructs are shown in the table; IN, BR1 and BP1 are fixed parameters 
Per Table 3, Cronbach's $\alpha$, which measures the model variables' reliability, was between $0.897-0.925$ for every construct and its respective subscales; these values, which exceeded the 0.7 threshold, verified the constructs' internal consistency. Moreover, the constructs' discriminant and convergent validities were gauged. To evaluate the convergent validity, three indices were employed: factor loading values and composite reliability (CR) values exceeded the 0.7 threshold, and average variance extracted (AVE) values exceeded the 0.5 threshold [60]. Discriminant validity helps in differentiating one construct from the other. In this study, every construct's discriminant validity was confirmed by ensuring that the AVE's square root was greater than the association between that construct and the others. Overall, the tests of discriminant and convergent validity revealed satisfactory levels, which implied that for a structural model assessment, the research constructs had a suitable fit, and the model was adequate for further analysis.

\section{5-3- Structural Model and Hypotheses Testing}

The hypotheses tests were utilised to evaluate the structural model. IBM AMOS software (version 22) provided a path analysis for investigating the causal model. The model's goodness-of-fit indicators were as follows: root mean square error of approximation $(\mathrm{RMSEA})=0.049$; comparative fit index $(\mathrm{CFI})=0.938$; Tucker Lewis index $(\mathrm{TLI})=$ 0.943; normal fit index $(\mathrm{NFI})=0.942$; goodness-of-fit index $(\mathrm{GFI})=0.935$; $\mathrm{df}=314$; chi-square $=732.293$; and minimum discrepancy per degree of freedom $(\mathrm{CMIN} / \mathrm{df})=2.332$. These indicators fell within the cutoff values, suggesting a good model fit. Table 4 illustrates the hypotheses test results that indicate the significance of the variables' relationships.

Table 4. Hypotheses testing.

\begin{tabular}{lccc}
\hline \multicolumn{1}{c}{ Hypothesis } & Loading & t-value & Result \\
\hline Hypothesis 1 (H1): The 7I's of effective viral marketing have a positive, direct impact on brand preference. & 0.298 & 4.938 & Supported \\
Hypothesis 2 (H2): The 7I's of effective viral marketing have a positive, direct impact on brand recognition. & 0.440 & 6.373 & Supported \\
Hypothesis 3 (H3): Brand recognition has a positive, direct impact on brand preference. & 0.653 & 8.135 & Supported \\
\hline
\end{tabular}

The regression results indicated that the 7I's have a significant positive effect on brand preference $(\mathrm{SE}=0.071 ; \beta=$ 0.298; $\mathrm{p}<0.001$; supporting H1) and brand recognition ( $\mathrm{SE}=0.09 ; \beta=0.440 ; \mathrm{p}<0.001$; supporting H2). The structural equation modelling results also illustrated that brand recognition has a significant positive influence on brand preference $(\mathrm{SE}=0.07 ; \beta=0.653 ; \mathrm{p}<0.001 ;$ supporting H3).

To test the potential mediating effect of brand recognition on the relationship between the 7I's and brand preference, a bootstrapping technique was utilised. The outcome of the mediation analysis with bootstrapping illustrated that the 7I's have a direct effect on brand recognition $(0.298 ; \mathrm{p}<0.001 ; 95 \% \mathrm{CI}[0.171,0.422])$ and a considerable indirect effect on brand preference through brand recognition $(0.287 ; \mathrm{p}<0.001 ; 95 \%$ CI [0.197, 0.389]), confirming partial mediation. Table 5 illustrates the outcomes of the mediation analysis with bootstrapping.

Table 5. Mediation analysis results.

\begin{tabular}{lcccc}
\hline \multicolumn{1}{c}{ Hypothesis } & Direct effect & Indirect effect & Result \\
\hline H4: Brand recognition mediates the effect of the 7I's on brand preference. & $0.298(* * *)$ & $0.287(* * *)$ & Partial mediation \\
\hline Note: $* * * \mathrm{p}<0.001$. & & &
\end{tabular}

To test H5, multi-group moderation tests were conducted to explore the variation effect of the antecedent variable (the 7I's) on the dependent variables (brand recognition and preference). For these tests, the respondents were divided into two groups (younger and older). The younger group, which included 167 respondents, was defined as those who were 35 years of age or younger. Meanwhile, the older group included the 119 respondents who were older than 35.

To test the categorical moderation hypothesis, we used AMOS to produce critical ratios for the differences in regression weights between groups of generational difference (younger and older). Gaskin and Lim (2018) recommended a statistical tools package for testing multi-group moderation effects that uses regression weights and critical ratios for difference parameters [61]. The relevant models were analysed separately for these categorical groups and cross-checked with their respective regression weights and critical ratios for group differences (Table 6) via the statistical tools package [61].

Table 6. Path analysis of moderation effect-group differences.

\begin{tabular}{|c|c|c|c|c|c|c|c|c|}
\hline \multirow{2}{*}{\multicolumn{4}{|c|}{$\begin{array}{c}\text { Hypothesis } \\
\text { Structural path and direction }\end{array}$}} & \multicolumn{2}{|c|}{ Younger } & \multicolumn{2}{|c|}{ Older } & \multirow{3}{*}{\begin{tabular}{|l} 
Z-score \\
$3.104^{* *}$
\end{tabular}} \\
\hline & & & & \multirow{2}{*}{$\begin{array}{c}\text { Estimate } \\
0.336\end{array}$} & \multirow{2}{*}{\begin{tabular}{c|}
$\mathbf{p}$ \\
0.000
\end{tabular}} & \multirow{2}{*}{$\begin{array}{c}\text { Estimate } \\
0.278\end{array}$} & \multirow{2}{*}{$\begin{array}{c}\mathbf{p} \\
0.000\end{array}$} & \\
\hline H5 & $\mathrm{BP}$ & $\leftarrow$ & 7I's & & & & & \\
\hline
\end{tabular}

According to Table 6 , the 7I's significantly and positively enhanced brand preference in both the younger $(\beta=0.336$, $\mathrm{p}<0.001)$ and older $(\beta=0.278, \mathrm{p}<0.001)$ groups. However, the 7I's effects on brand preference were more prominent in the younger group. Therefore, H5 is supported. 
The results of the structural equation modelling analysis provide additional insight into the impacts of viral marketing initiatives on targeted audiences' brand recognition and preference. Our findings confirm previous studies by Mustikasari \& Widaningsih (2018) and Nguyen \& Nguyen (2020) that effective viral marketing initiatives have a positive direct impact on targeted audiences' brand recognition [62, 63]. Therefore, marketers and businesses should adopt the 7I's concept to ensure that they are creating appropriate content for effective viral marketing campaigns. Marketers and businesses should also exploit social media platforms as the main medium for viral campaigns; indeed, the speed and ease with which audiences can share content via such platforms places social media among the most effective tools for businesses [64]. Additionally, the results reveal that effective viral marketing campaigns can significantly and positively affect targeted audiences' brand preference. This finding is consistent with Liu and Wang (2019) and Arici and Arici (2021), who reported that viral marketing influences customer-based brand equity and purchase intention. Consequently, if an individual interacts with viral marketing campaigns, his or her BP is likely to increase, which, subsequently, increases the possibility that the individual will purchase the advertised brands, products or services $[65,66]$.

Furthermore, the results of the moderation effect testing between the older and younger groups reveal that the effect of viral marketing campaigns on brand preference is stronger among younger than older audiences. This finding aligns with Libert (2014), who noted that people in different age groups respond differently to similar viral marketing campaigns [67]. Therefore, marketers and enterprises must account for certain demographic factors, such as age, before executing viral marketing campaigns. The content of viral marketing messages must be customised and sent only after demographic or psychographic segmentation.

\section{6- Conclusion}

The penetration of digital technology and internet infrastructure into consumers' lives during the past decade has changed the very nature of online advertising. Marketers now recognise — and must capitalise on-new opportunities to accelerate the spread of marketing messages through customer-to-customer interactions, or viral marketing. Viral marketing departs from traditional word-of-mouth marketing in its reliance on the agility of digital resources, including mobile phones and the Internet [15]. As mentioned previously, viral marketing is more beneficial for companies than traditional above-the-line media due to the lower levels of investment (cost) involved in devising viral marketing campaigns and the potential of such campaigns to reach larger audiences [21]. Although, theoretically, marketers can thus derive key advantages from viral marketing, the major disadvantage of such campaigns is the relative lack of control they allow marketers to exert over the message and its distribution [13]. While we anticipate significant growth of viral marketing in the future, the results of viral marketing initiatives can be costly for marketers if audiences perceive messages negatively. Companies should be aware of this risk because even high brand equity can be significantly diluted by negative messages [10]. To date, only limited research has examined the elements of successful viral marketing campaigns. The present research works to close this gap by providing guidelines for creating effective viral marketing campaigns. This study has important implications for marketers to achieve their communication goals efficiently and effectively. Based on the present study's findings, seven factors (the 7I's) influence successful viral marketing through social media: Identity, Innovation, Insight, Instantaneity, Integration, Interactivity and Invisibility. While many marketers fixate on the size of the audiences that their viral messages can reach (Index), this study finds that effective viral marketing through the 7I's framework has a significant positive effect on brand recognition and preference. The results of the moderating effect testing also reveal that the impact of viral marketing on brand preference is greater among younger participants than older participants. Our findings thus provide insights for both academics and practitioners, suggesting that successful viral marketing campaigns depend significantly on the quality of the content (Influential). By understanding the 7I's framework of successful viral marketing campaigns in social media contexts, companies can more accurately predict which viral marketing approach will become widely successful and why.

\section{6-1- Limitations and Future Research}

The proposed 7I's framework for successful viral marketing provides practitioners and researchers with an overview of different contexts from which to further explore or challenge the framework derived. Despite this study's theoretical and practical contributions, it also entails limitations. Because its results depend on a self-administered questionnaire and respondents' perceptions, the most significant limitation of this research is the generalisability of its findings. The limitation of data collection to respondents in Thailand further restricts the study's generalisability and requires additional research in other countries with different cultures to capture the effects of cultural differences.

\section{7- Declarations}

\section{7-1-Author Contributions}

W.P. conceptualized and participated study design, coordinated data collection, carried out the initial analyses, drafted the initial manuscript, and read and approved the manuscript. S.T. participated in study design, guided the methodology coordinated and supervised data collection and analyses, reviewed and edited manuscript. Both authors read and approved the manuscript as submitted and agree to be accountable for all aspects of the work. 


\section{7-2-Data Availability Statement}

The data presented in this study are available on request from the corresponding author.

\section{7-3- Funding}

The authors received no financial support for the research, authorship, and/or publication of this article.

\section{7-4- Conflicts of Interest}

The authors declare that there is no conflict of interests regarding the publication of this manuscript. In addition, the ethical issues, including plagiarism, informed consent, misconduct, data fabrication and/or falsification, double publication and/or submission, and redundancies have been completely observed by the authors.

\section{8- References}

[1] Motoki, Kosuke, Shinsuke Suzuki, Ryuta Kawashima, and Motoaki Sugiura. "A Combination of Self-Reported Data and SocialRelated Neural Measures Forecasts Viral Marketing Success on Social Media.” Journal of Interactive Marketing 52 (2020): 99117. doi:10.1016/j.intmar.2020.06.003.

[2] Klopper, H.B. "Viral Marketing: A Powerful, but Dangerous Marketing Tool.” SA Journal of Information Management 4, no. 2 (2002). doi:10.4102/sajim.v4i2.159.

[3] Sharma, Rishi Raj, and Balpreet Kaur. "E-Mail Viral Marketing: Modeling the Determinants of Creation of 'Viral Infection."” Management Decision 58, no. 1 (2020): 112-28. doi:10.1108/MD-03-2017-0215.

[4] Bolton, Ruth N., A. Parasuraman, Ankie Hoefnagels, Nanne Migchels, Sertan Kabadayi, Thorsten Gruber, Yuliya Komarova Loureiro, and David Solnet. "Understanding Generation Y and Their Use of Social Media: A Review and Research Agenda." Journal of Service Management 24, no. 3 (2013): 245-67. doi:10.1108/09564231311326987.

[5] Gao, Chuangen, Hai Du, Weili Wu, and Hua Wang. "Viral Marketing of Online Game by DS Decomposition in Social Networks." Theoretical Computer Science 803 (2020): 10-21. doi:10.1016/j.tcs.2019.03.006.

[6] Oraedu, Chukwunonso, Ernest Emeka Izogo, Justie Nnabuko, and Ike Elechi Ogba. "Understanding Electronic and Face-to-Face Word-of-Mouth Influencers: An Emerging Market Perspective.” Management Research Review 44, no. 1 (2021): 112-32. doi:10.1108/MRR-02-2020-0066.

[7] Marinova, Iva. "Word of Mouth Marketing Statistics, Fun Facts \& Tips in 2020." Review 42 (2021). Available online: https://review42.com/resources/word-of-mouth-marketing-statistics/ (accessed on April 2021).

[8] Woerdl, M., Savvas Papagiannidis, Michael A. Bourlakis, and Feng Li. "Internet-induced marketing techniques: Critical factors in viral marketing campaigns." Journal of Business Science and Applied Management 3, no. 1 (2008): 35-45.

[9] Aaker, David A. "Leveraging the Corporate Brand." California Management Review 46, no. 3 (2004): 6-18. doi:10.1177/000812560404600301.

[10] Arora, Poonam, and Carolyn E. Predmore. "Social media as a strategic tool: Going beyond the obvious." Social media in strategic management (Advanced Series in Management) 11, (2013): 115-127. doi:10.1108/S18776361(2013)0000011010.

[11] Wang, Ping, Luping Sun, and Luluo Peng. "Modeling Product Attitude Formation Process in Online Word-of-Mouth.” Nankai Business Review International 4, no. 3 (2013): 212-29. doi:10.1108/NBRI-07-2013-0025.

[12] Fu, Jen Ruei, Pei Hung Ju, and Chiung Wen Hsu. "Understanding Why Consumers Engage in Electronic Word-of-Mouth Communication: Perspectives from Theory of Planned Behavior and Justice Theory." Electronic Commerce Research and Applications 14, no. 6 (2015): 616-30. doi:10.1016/j.elerap.2015.09.003.

[13] Kiran, Vasanth, Mousumi Majumdar, and Krishna Kishore. "Marketing the Viral Way: A Strategic Approach to the New Era of Marketing." International Journal of Management and Social Sciences Research 1, no. 3 (2012): 1-5.

[14] Cruz, Danilo, and Chris Fill. "Evaluating Viral Marketing: Isolating the Key Criteria.” Marketing Intelligence and Planning 26, no. 7 (2008): 743-58. doi:10.1108/02634500810916690.

[15] Grewal, Anshu, and Vikas Chaha. "Viral Marketing: A Revolutionary Tool for Successful Marketing Campaigns." International Journal of Engineering, Management, Humanities and Social Sciences Paradigms (IJEMHS) 01, no. 01 (2013): 1-6.

[16] Sohn, Kyongsei, John T Gardner, and Jerald L Weaver. "Viral Marketing-More than a Buzzword.” Journal of Applied Business and Economics 14, no. 1 (2013): 21-42.

[17] Ferguson, Rick. "Word of Mouth and Viral Marketing: Taking the Temperature of the Hottest Trends in Marketing." Journal of Consumer Marketing 25, no. 3 (2008): 179-82. doi:10.1108/07363760810870671. 
[18] Libai, Barak, Ruth Bolton, Marnix S. Bügel, Ko de Ruyter, Oliver Götz, Hans Risselada, and Andrew T. Stephen. "Customerto-Customer Interactions: Broadening the Scope of Word of Mouth Research.” Journal of Service Research 13, no. 3 (2010): 267-82. doi:10.1177/1094670510375600.

[19] Stonedahlt, Forrest, William Rand, and Uri Wilenskyt. "Evolving Viral Marketing Strategies." In Proceedings of the 12th Annual Genetic and Evolutionary Computation Conference, GECCO '10, (2010):1195-1202. doi:10.1145/1830483.1830701.

[20] Kaplan, Andreas M., and Michael Haenlein. "Two Hearts in Three-Quarter Time: How to Waltz the Social Media/Viral Marketing Dance.” Business Horizons 54, no. 3 (2011): 253-63. doi:10.1016/j.bushor.2011.01.006.

[21] Dobele, Angela, David Toleman, and Michael Beverland. "Controlled Infection! Spreading the Brand Message through Viral Marketing.” Business Horizons 48, no. 2 (2005): 143-49. doi:10.1016/j.bushor.2004.10.011.

[22] Rezvani, Mehran, Shahram Ghahramani, and Kiandokht Kiaee. "An Investigation of Viral Marketing Effects on CostumerBased Brand Equity in Mobile Market." Middle East Journal of Scientific Research 18, no. 3 (2013): 376-81. doi:10.5829/idosi.mejsr.2013.18.3.11898.

[23] Allsop, Dee T., Bryce R. Bassett, and James A. Hoskins. "Word-of-Mouth Research: Principles and Applications.” Journal of Advertising Research 47, no. 4 (2007): 398-411. doi:10.2501/S0021849907070419.

[24] Makinde, Olusola Oladapo. "The Effects of Physical and Social Characteristics on Residents' Perception on Neighbourhood Quality in the Urban Environment." Journal of Human, Earth, and Future 1, no. 3 (2020): 122-145. doi:10.28991/hef-2020-0103-03.

[25] Walsh, Gianfranco, Vincent Wayne Mitchell, Paul R. Jackson, and Sharon E. Beatty. "Examining the Antecedents and Consequences of Corporate Reputation: A Customer Perspective.” British Journal of Management 20, no. 2 (2009): $187-203$. doi:10.1111/j.1467-8551.2007.00557.x.

[26] Bickart, Barbara, and Robert M. Schindler. "Internet Forums as Influential Sources of Consumer Information.” Journal of Interactive Marketing 15, no. 3 (2001): 31-40. doi:10.1002/dir.1014.

[27] East, Robert, Kathy Hammond, and Wendy Lomax. "Measuring the Impact of Positive and Negative Word of Mouth on Brand Purchase Probability." International Journal of Research in Marketing 25, no. 3 (2008): 215-24. doi:10.1016/j.ijresmar.2008.04.001.

[28] Pescher, Christian, Philipp Reichhart, and Martin Spann. "Consumer Decision-Making Processes in Mobile Viral Marketing Campaigns.” Journal of Interactive Marketing 28, no. 1 (2014): 43-54. doi:10.1016/j.intmar.2013.08.001.

[29] Davis, Duane L.; Guiltinan, Joseph P.; Jones, Wesley H. "Service Characteristics, Consumer Search and the Classification of Retail Services.Pdf.” Journal of Marketing Research 55, no. 3 (1983): 393-404.

[30] Litvin, Stephen W., Ronald E. Goldsmith, and Bing Pan. "Electronic Word-of-Mouth in Hospitality and Tourism Management." Tourism Management 29, no. 3 (2008): 458-68. doi:10.1016/j.tourman.2007.05.011.

[31] Prins, Remco, and Peter C. Verhoef. "Marketing Communication Drivers of Adoption Timing of a New E-Service among Existing Customers.” Journal of Marketing 71, no. 2 (2007): 169-83. doi:10.1509/jmkg.71.2.169.

[32] Ho, Jason Y.C., and Melanie Dempsey. "Viral Marketing: Motivations to Forward Online Content." Journal of Business Research 63, no. 9-10 (2010): 1000-1006. doi:10.1016/j.jbusres.2008.08.010.

[33] López, Manuela, and María Sicilia. "How WOM Marketing Contributes to New Product Adoption: Testing Competitive Communication Strategies.” European Journal of Marketing 47, no. 7 (2013): 1089-1114. doi:10.1108/03090561311324228.

[34] Wenqi, Shen, and Jungpil Hahn. "Impact of Online Word-of-Mouth on the Market for Consumer Goods-the Interplay between Adoption Rate, Product Market Life and Market Size.” West Lafayette, IN: Purdue University, USA (2008).

[35] Harridge-March, Sally, and Sarah Quinton. "Virtual Snakes and Ladders: Social Networks and the Relationship Marketing Loyalty Ladder.” The Marketing Review 9, no. 2 (2009): 171-81. doi:10.1362/146934709x442692.

[36] Blazevic, Vera, Wafa Hammedi, Ina Garnefeld, Roland T. Rust, Timothy Keiningham, Tor W. Andreassen, Naveen Donthu, and Walter Carl. "Beyond Traditional Word-of-Mouth: An Expanded Model of Customer-Driven Influence." Journal of Service Management 24, no. 3 (2013): 294-313. doi:10.1108/09564231311327003.

[37] Miquel-Romero, María José, and Consolacion Adame-Sánchez. "Viral Marketing through E-Mail: The Link CompanyConsumer." Management Decision 51, no. 10 (2013): 1970-82. doi:10.1108/MD-08-2012-0592.

[38] Jalilvand, Mohammad R., and Neda Samiei. "The Effect of Electronic Word of Mouth on Brand Image and Purchase Intention: An Empirical Study in the Automobile Industry in Iran.” Marketing Intelligence and Planning 30, no. 4 (2012): 460-76. doi:10.1108/02634501211231946.

[39] Tyler West. "Going Viral: Factors That Lead Videos to Become Internet Phenomena." The Elon Journal of Undergraduate Research in Communications 2, no. 1 (2011): 76-84. 
[40] Larson, R J. "The Rise of Viral Marketing through the New Media of Social Media." Faculty Publications and Presentations 6 (2009): 6.

[41] Angel, Robert, and Joseph Sexsmith. "Social Networking: The View from the C-Suite." Ivey Business Journal 73, no. 4 (2009): 5. Available online: https://iveybusinessjournal.com/publication/social-networking-the-view-from-the-c-suite/. (accessed on April 2021).

[42] Miller, Rohan, and Natalie Lammas. "Social media and its implications for viral marketing." Asia Pacific Public Relations Journal 11, no. 1 (2010): 1-9.

[43] Susskind, Alex M. "I Told You so! Restaurant Customers' Word-of-Mouth Communication Patterns." Cornell Hotel and Restaurant Administration Quarterly 43, no. 2 (2002): 75-85. doi:10.1016/S0010-8804(02)80034-9.

[44] Hann, Il Horn, Kai Lung Hui, Sang Yong T. Lee, and Ivan P.L. Png. "Consumer Privacy and Marketing Avoidance: A Static Model.” Management Science 54, no. 6 (2008): 1094-1103. doi:10.1287/mnsc.1070.0837.

[45] Southgate, Duncan, Nikki Westoby, and Graham Page. "Creative Determinants of Viral Video Viewing." International Journal of Advertising 29, no. 3 (2010): 349-68. doi:10.2501/S0265048710201221.

[46] Ibeh, Kevin I N, Ying Luo, and Keith Dinnie. "E-Branding Strategies of Internet Companies: Some Preliminary Insights from the UK." Journal of Brand Management 12, no. 5 (2005): 355-73. doi:10.1057/palgrave.bm.2540231.

[47] Kotler, P, and K L Keller. Marketing Management. Soldering \& Surface Mount Technology. Global Edi. Vol. 13. Harlow, United Kingdom: Pearson Education Limited.", 2001. doi:10.1108/ssmt.2001.21913cab.040.

[48] Berger, Jonah, and Katherine L. Milkman. “What Makes Online Content Viral?” Journal of Marketing Research 49, no. 2 (2012): 192-205. doi:10.1509/jmr.10.0353.

[49] wu, Paul C.s., and Yun Chen Wang. "The Influences of Electronic Word-of-Mouth Message Appeal and Message Source Credibility on Brand Attitude." Asia Pacific Journal of Marketing and Logistics 23, no. 4 (2011): 448-72. doi:10.1108/13555851111165020.

[50] Baird, Carolyn Heller, and Gautam Parasnis. "From Social Media to Social Customer Relationship Management." Strategy and Leadership 39, no. 5 (2011): 30-37. doi:10.1108/10878571111161507.

[51] Fisher, Tia. "ROI in Social Media: A Look at the Arguments." Journal of Database Marketing and Customer Strategy Management 16, no. 3 (2009): 189-95. doi:10.1057/dbm.2009.16.

[52] Abrantes, José Luís, Cláudia Seabra, Cristiana Raquel Lages, and Chanaka Jayawardhena. "Drivers of In-Group and out-ofGroup Electronic Word-of-Mouth (EWOM).” European Journal of Marketing 47, no. 7 (2013): $1067-88$. doi:10.1108/03090561311324219.

[53] Jahn, Benedikt, and Werner Kunz. "How to Transform Consumers into Fans of Your Brand." Journal of Service Management 23, no. 3 (2012): 344-61. doi:10.1108/09564231211248444.

[54] Anderson, James C., and David W. Gerbing. "Structural Equation Modeling in Practice: A Review and Recommended TwoStep Approach.” Psychological Bulletin 103, no. 3 (1988): 411-23. doi:10.1037/0033-2909.103.3.411.

[55] Bentler, P. M., and Chih Ping Chou. "Practical Issues in Structural Modeling." Sociological Methods \& Research 16, no. 1 (1987): 78-117. doi:10.1177/0049124187016001004.

[56] Kline, Rex B. "Principles and practice of structural equation modeling (3. Bask1)." New York, NY: Guilford (2011).

[57] Awad Alhaddad, Abdullah. "The Effect of Advertising Awareness on Brand Equity in Social Media." International Journal of E-Education, e-Business, e-Management and e-Learning 5, no. 2 (2015): 73-84. doi:10.17706/ijeeee.2015.5.2.73-84.

[58] Ebrahim, Reham, Ahmad Ghoneim, Zahir Irani, and Ying Fan. "A Brand Preference and Repurchase Intention Model: The Role of Consumer Experience." Journal of Marketing Management 32, no. 13-14 (2016): 1230-59. doi:10.1080/0267257X.2016.1150322.

[59] Awang, Z. SEM Made Simple: A Gentle Approach to Learning Structural Equation Modelling. MPWS Rich Publication. Vol. 1. MPWS Rich Publication, (2015).

[60] Hair, Joseph, William Black, Barry Babin, and Rolph Anderson. Multivariate Data Analysis: A Global Perspective. Multivariate Data Analysis: A Global Perspective. Eds. 7th. Pearson Upper Saddle River, (2010).

[61] Gaskin, J., and J Lim. “Multigroup Analysis, AMOS Plugin. Gaskination's StatWiki.” Gaskination's StatWiki, 2018. Available online: http://statwiki.kolobkreations.com/index.php?title=Main_Page. (accessed on May 2021)

[62] Mustikasari, Ati, and Sri Widaningsih. “The Influence of Viral Marketing toward Brand Awareness and Purchase Decision.” In 1st International Conference on Economics, Business, Entrepreneurship, and Finance (ICEBEF 2018), 2019. doi:10.2991/icebef18.2019.138. 
[63] Nguyen, Cuong, and Danh Nguyen. "A Study of Factors Affecting Brand Awareness in the Context of Viral Marketing in Vietnam.” International Journal of Advanced Science and Technology 29, no. 5 (2020): 5401-11. doi:10.2139/ssrn.3906104.

[64] Bhattacharya, Saumik, Kumar Gaurav, and Sayantari Ghosh. "Viral Marketing on Social Networks: An Epidemiological Perspective.” Physica A: Statistical Mechanics and Its Applications 525 (2019): 478-90. doi:10.1016/j.physa.2019.03.008.

[65] Liu, Hsiang-Hsi, and Yu-Ning Wang. "Interrelationships between Viral Marketing and Purchase Intention via Customer-Based Brand Equity.” Journal of Business and Management Sciences 7, no. 2 (2019): 72-83. doi:10.12691/jbms-7-2-3.

[66] Arici, Hasan Evrim, and Nagihan Cakmakoglu Arici. “The Role of Social Media Marketing Activities on International Students' Brand Preference: A Study on English-Speaking Universities of Germany.” In Global Perspectives on Recruiting International Students: Challenges and Opportunities, 51-64, 2021. doi:10.1108/978-1-83982-518-720211003.

[67] Libert, Kelsey. "Age and gender matter in viral marketing." Harvard Business Review (2014). 